Fecha de recepción: diciembre 2017 Fecha de aceptación: octubre 2018 Versión final: julio 2019

\section{Julie Doucet, between order and disorder}

Mira Falardeau *

\begin{abstract}
This article intends to present and analyse the links between two types of discourse in the creations of the Montrealer artist, Julie Doucet. The comix chosen is Dirty Plotte, number 5, published in 1992 by Drawn \& Quarterly (Montreal) and republished in French in 2013 as Fantastic Plotte by L'Oie de Cravan (Montreal). We first present the artist Doucet, secondly, we examine the story of What an Intense City, and thirdly, the synopsis of Missing. Subsequently, we analyse the two types of discourse, comparing the underground language used in the first work to the conventional one used in Missing, observing the image as well as the narration. Our hypothesis is that the creation of Missing, one of the most brilliant works of Doucet, was possible because of her ability to understand the two different languages and to go from one to the other. The analysis considers iconic elements and rhetorical figures. The detailed analysis of diverse elements of background and characters will reveal a strong contrast between both works. The deciphering of rhetorical figures, narrative as well as visual, will demonstrate how the practice of an alternative and experimental art succeeded in enriching the artist and gave her tools to communicate with all types of public in respect of conventional codes. Between three cultures, Doucet, a francophone who writes in English with "the accent", plays on several levels and her discourse creates links between American and Canadian underground, the art of Montreal metropolis and the cheeky humour of French alternative press.
\end{abstract}

Keywords: Julie Doucet - Canadian comics - underground comics - visual analysis.

[Abstracts in Spanish and Portuguese on pages 44-45]

${ }^{(*)}$ Mira Falardeau. Master in Art History (1978), Laval University, Quebec. PhD in Sciences of Art (1981), La Sorbonne, Paris. Professor in Communication, University of Ottawa (1983-84), Cegep Sainte-Foy (1987-89), Cegep Limoilou, Quebec (1998-2005). Lecturer in Laval University (1975-77) (1991). Guest Curator for great exhibitions on comics: MNBAQ, Quebec (1997), BANQ, Montreal (2005, 2008, 2011-13). Author of seven essays.

Our purpose in this article is to demonstrate a phenomenon we often notice in our researches: the link between the underground discourse and the conventional one. Indeed, we are convinced the two discourses not only respond to each other but also nourish one 
another. The particularity here being the two forms remain together in the same comics signed by the same author.

The comix ${ }^{1}$ chosen is Dirty Plotte, number 5, published in 1992 by Drawn \& Quarterly (Montreal) and republished in French in 2014 as Fantastic Plotte by L'Oie de Cravan (Montreal). The two works analyzed in this article are included in the above comix and are entitled: What an Intense City, three pages, and Missing. Another Bad Dream, a twelve pages story. The first analysis will be a visual one and the second, a narrative one, placing the emphasis on Missing because it reveals a rupture with the typical underground language of Doucet.

\section{Presentation}

Underground cartoonist Julie Doucet is the only Quebecker woman cartoonist who has gained an international reputation. Indeed, she was selected as one of the greatest artists of the contemporary world of comics by the 2003 Beaux-Arts Magazine (Paris). She was born in 1965 in Saint-Lambert in the Montreal area. She studied visual arts at the Cegep ${ }^{2}$ du Vieux Montreal, then at the University of Quebec in Montreal where she specialized in the arts of printing. During her twenties, she enjoyed participating in comics fanzines called "comix". From 1988 to 1990, she self-published a series of fanzines evocatively titled Dirty Plotte (14 issues), indicating immediately Doucet's provocative tone. Years later, in 2010, she described her beginnings:

"When I first started to draw comics, I wasn't starting a career. I didn't even expect to ever be published: such a thing seemed to be impossible. It was in the 80 's, there really was no future at the time, so might as well do something you liked. This was for me drawing silly stories. No censorship whatsoever, total freedom. I knew guys who were doing fanzines. I joined them, but eventually got frustrated with them because they were too lazy, too slow. So, I decided to create my own. It was my home, my art space."

Doucet's peculiarity was to belong to the English-speaking underground world as she claimed from the start, even if she was French-speaking. Her choice to write her dialogues in English, giving a kind of "French accent" to her texts, was accompanied by a dual loyalty she herself maintained between two worlds: the American alternative comics and the French ones. Obviously, we must say most of Doucet's titles are difficult to translate. This tittle Dirty Plotte is very funny for a Quebecker reader. She uses the English word "dirty" (salacious, unclean) and the Quebec French slang word "plotte" (vulva, pussy, cunt) to produce a veritable bilingual double-entendre that can be understood as "salacious plot" (the story line) or as "dirty cunt" (the character). She recently used, in 2013, a similarly ambiguous title, Fantastic Plotte, for a collection in French of her previous comics. We are here analyzing the fifth issue of her first collection of comix. Her self-published comix were rapidly reprinted by the Montreal publisher Drawn \& Quarterly. Then, she saw her works included in the American West Coast women cartoonists' comix, Wimmen's 
Comix, then in the famous father of the American underground, Robert Crumb's magazine Weirdo, and in France, in Chacal Puant magazine. Dirty Plotte was published under a comic book form, from 1991 to 1993 with various titles including Lève ta jambe, mon poisson est mort (1993) ${ }^{4}$. In My Most Secret Desire (1995), she brought together a series of short stories equally delusional. Her boxes were literally exploding under a barrage of crushed lines where bloody human beings were screaming and belching one after the other. Doucet was very conscious of her originality. Women cartoonists are rare in that incredible world of underground comix where everything can be said and showed. And she shares with the American cartoonist Lynda Barry ${ }^{5}$ (1956- ) the talent to reach a special place in the alternative field of comics, as she realized: "I felt like a girl going to work building houses with the carpenter guys. They were nice. I was something of a curiosity, such a sweet looking girl I was, and drawing such dirty comics. I immediately got respect anyway."

Doucet then saw her fame cross the American border. She left for a seven years journey which led her first to the United States and then, to Europe. There, she drew My New York Diary / Chroniques de New York $(1999,2003)$ and also produced Ciboire de criss (1996) and Changements d'adresse (1998). Fifteen albums appeared in both languages during these prolific years. She went increasingly towards an autobiographical path with L'affaire madame Paul/ The Madame Paul Affair (1999, 2000), a crazy and wacky graphic novel.

Between 2000 and 2018, she has quit the world of comics, given priority to woodcut, linocut and screen printing, and has participated in collective works and artists' books. Through her presence in major art museum exhibitions, she bridged the gap between noble and popular arts with both her parodic and poetic montages. Her last works were, at L'Oie de Cravan Publ., Melek with Benoît Chaput (2002), I am a K (2006), À l'école de l'amour (2008) and Der Stein, her German fanzine, in eight issues attesting to her continuous research into new languages. This time, she combined collages and original prints, leaving the paroxysms of violence of her youth for a more lyrical way. She continued with self-published poetic serigraphs assembled in what she called "texts-collages". In 2012, she signed "Aaarg" for the Stables Theatre and many artistic texts-collages. The same year, she started a publishing house in Montreal Le Pantalitaire for her own works and produced Un, deux, trois, je ne suis plus là (2013), poetic collages, and ten short animation films called Noodles/Nouilles. Poirette number 1 and 2 (2018) has the subtitle of "minimalistic feminist fanzine". To summarize, Doucet had two different phases in her creation: the development of her creator's career in underground comix in the 80s and 90s, then, since 2000, an important turning point to artistic collages and lithographs.

\section{Analysis}

The two following stories are quite different. In the first one, a three pages work entitled What an Intense City (Figure 1) ${ }^{7}$, Julie stands as "I" in a New York street, slightly startled by the big city, while objects speak and move in a ceaseless ballet. She just arrived in the city and seems very excited to be there: "I'm in New York city! My friend's place is just on this street...". 


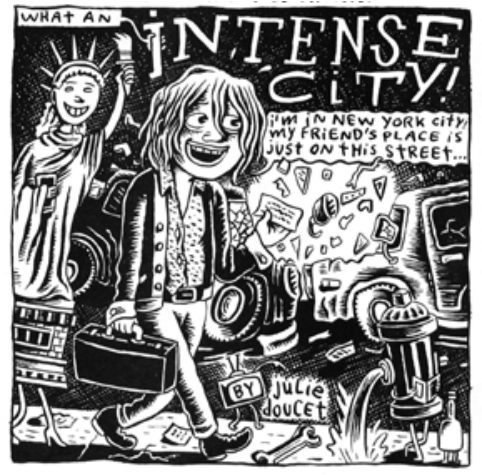

Figure 1. Doucet J. (1992)

What an Intense City p.1.

(C) 1992 Julie Doucet.

But rapidly, her joy disappears: she gets watered by a talking fire hydrant. Then suddenly, her luggage is stolen and in the next box, the masked thief is hurt by a car. To console her, garbage talks to her "Let's get drunk!" while she is crying in front of all these misadventures. Human beings seem without soul, as automatons and the objects seem alive. Boxes are overloaded with action: in the same box where she gets robbed, a guy posts a letter in a mailbox, and the mailbox answers: "Thank you sir". On the other hand, objects make life tough for Julie. In the background, the wounded thief seems of no interest to anybody. But the stolen wallet jumps from the hands of the thief at the time of the accident and ends up in the hands of delighted cans. Julie's trip ends in the cubbyhole of her friend, a talking mouse named Mike, suggesting Mickey Mouse. The tone is grotesque and the end, funny.

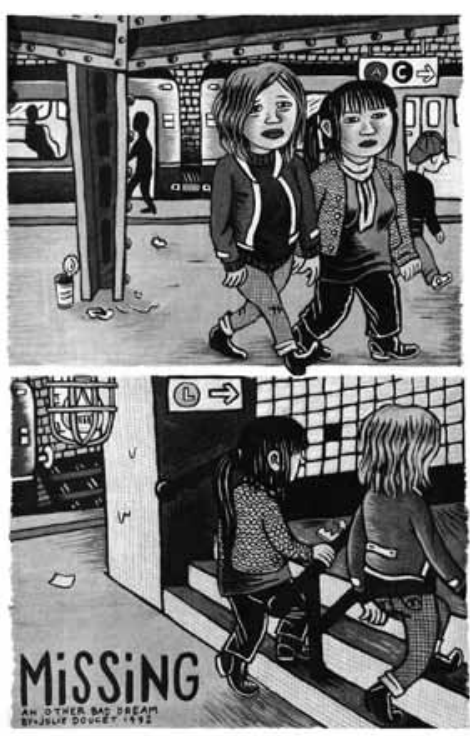

Figure 2. Doucet, J. (1992). Missing. Another bad dream, p.1. (C) 1992 Julie Doucet. 
The second work of twelve pages, Missing, is, in contrast, a very uncluttered and almost metaphysical piece. It opens on the image (Figure 2) of two girls walking in the subway. The "I" of the author walks with her friend Brigitte of Asian origin, an allusion to the multiethnic characteristic of large cities. While roaming in this underground and locked atmosphere, the central character loses three persons successively. The first one is her friend who suddenly disappears. This first scene unfolds very slowly, throughout seven pages with tall boxes, where Julie realizes Brigitte isn't with her anymore. She begins to look after her, retracing her steps then turning into a tunnel. The following images look like a labyrinth sequence, she turns in circle, calling out loud: "Why did she do that??" Finally, she concludes: "No Brigitte around..." and at that very moment, the second sequence begins. A guy springs from a detour and grabs her by the shoulder: "Julie! Nicolas is dead!!!" She seems sad when they both watch a stretcher carrying a body covered with a sheet, but not as devastated as the guy next to her crying and moaning after his friend. We suppose he committed suicide by dashing under the subway. This very short moment of one page and a half is rapidly interrupted by a public phone ringing close to Julie. She answers and immediately begins the last sequence of three pages and a half but their rhythm and nature break with the others: they contain very tight dialogues. In a suite of shots and reverse shots, we see the two protagonists, Julie and a friend called John, exchanging on the theme of an eventual weeding. John seems upset, he is sweaty but Julie, for her part, looks really relaxed, smiling and laughing about this funny idea they had had in order to give her American nationality. Finally, she asks the fundamental question: whether it is for help or for love and suddenly, he hangs up. She then finds herself alone after these three successive losses screaming in the phone: "Hello, hello, hello?

Following Gombrich's (1960) reflection about the notion of experimentation, we often noticed the power of free art on artistic creation. In our essay about the history of comics $(2008,154)$, we indicated: "The fanzine existing outside of any structure and, consequently, of all censorship, is the place for visual and narrative experiments. It constitutes a laboratory where young artists take a bath of freedom.” The phenomenon springs out with clarity in the Doucet comix Dirty Plotte. Our hypothesis is that the creation of Missing, one of Doucet's most brilliant works, was possible because of her ability to understand two different languages, the experimental one and a more conventional one, and to go from one to the other.

Our analysis considers iconic elements, then narrative ones. The differences between the two works are obvious. In fact, these two comix are often radically in opposition, an aspect also rich in information. These ruptures signify a reject of conventions and the important place of experimentation in the underground discourse. In fact, during most part of her career in comics, Doucet was resolutely an underground artist, without compromise. Her experimentations went in all directions, as we will see. In a second step, we will note similar elements, considering these as channels where exchanges are rich. Clearly, here is the heart of our study. The way Doucet has transformed language codes is particularly revealing of the richness of experimental art.

For the formal analysis, we will use our analysis grid, constantly refined during our researches. The principle is to consider the most common rhetorical figures in regard to each discourse element, from the simplest to the most complex: hence, from line and 
form to movement, action and dialogue. These rhetorical figures have mainly been chosen following Sigmund Freud's (1905/1960), Michel Melot's (1975) and Dominique Noguez' (1974) researches. For example, repetition is a figure we can find in lines, in forms, in movements, in dialogues or in the whole action. The figure of repetition has often been identified by many researchers, Bergson $(1901 / 1972,38)$ in the lead, to evocate a mechanical effect.

\section{Image}

At first sight, the visual aspects of the two stories contrast strongly. Most iconic elements are in total opposition. In What an Intense City (Figure1), typical underground comix, the first impression is one of disorder, upset. But after a quick look at the first image as a whole, we see Julie's smile and also, her happy words: she is very excited to be there. However, everything seems upside down, as if a disaster had just happened. A bomb, a hurricane? This upsetting impression is a kind of "signature" in comix in general. Exaggeration of outlines and numerous lines of movement are also common traits. The back of the scene is dark and hyper hatched, black bottom and white lines, all of which stress a feeling of oppression. The image extends beyond, suffocating the reader by its excess of strokes and forms. Apart the very large first image, the two other pages contain six boxes each, accentuating the sensation of clutter and jerks.

The white lines on that black stage could be interpreted as if the whole image could be a negative, like a photo negative. The black-white inversion gives a major sensation of an impossible world, still present, like in a nightmare. That feeling is reinforced as the action progresses by Julie's attitudes; she seems absolutely terrorized by what she sees. The more the story goes on, the more her facial expressions are excessive: bulging eyes, hair scattered in her face, tears running down her cheeks. In a sense, these manifestations are reassuring. She is normal; she reacts as anybody would have in the same situation.

In fact, the objects are alive. In an object-human anthropomorphism, they talk and move like human beings. The fire hydrant is the most sympathetic towards Julie, so to speak. It says: "Oh! I'm sorry!!" when it notices that its water is soaking Julie's pants, and "What an annoying situation!" with a good sense of compassion, when it learns that Julie has been robbed. Another type of objects has an important role in this comix: beer cans, walking around Julie's feet like little animals, and reacting to the action: "Hurray!", "Let's get drunk!" etc. Does it indicate a perception problem in the mind of the "I"? Is she stone, on a bad trip? Does the author mean that she is on drugs or that large cities are just too intense for the common person? Questions to which the narrative analysis will give answers. To summarize, exaggeration as a process is a major pivot of that comix. 


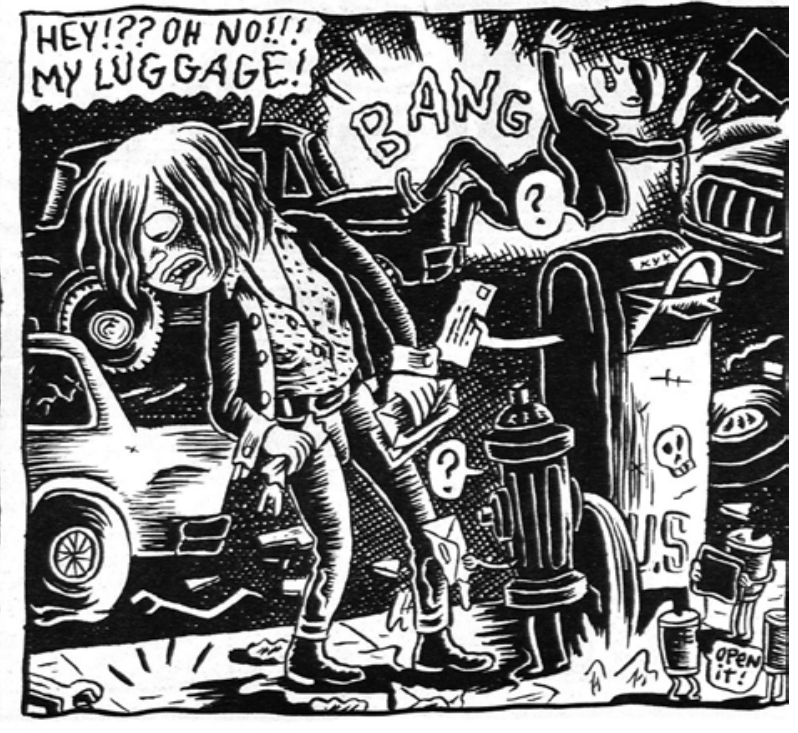

Figure 3. Doucet, J. (1992). What an intense city, p. 2, box 5. (C) 1992 Julie Doucet.

Simplification is also present in this story. As we noticed in our studies (2015), mixing the two basic figures, exaggeration and simplification, also called condensation, is typical of visual humor languages. A point also shown by numerous researches on humor carried out by Bergson, Melot and Noguez, we will later develop the effects on narration and message. Here, in Intense City, shots are as simplest as one can imagine: only one type of them during the whole story: an overall shot with fixed camera, recalling a theatre scene where people appear and disappear. That similarity of shots gives the reader the impression of just being spectator of a show, with a distance created by the fixity of the images. Julie herself seems to drift outside of her body as well as outside of the awesome street show. The first look at Missing gives exactly the opposite feeling. The image is clean, very sober. The grey, black, white colors and hatchings are distributed equally. The three first pages are airy, with only two boxes, then three and three, respectively for the pages 1,2 and 3. So we have time to go down into the story and to be part of the group.

Contrary to Intense City, in Missing, shots alternate, front view, back view. The kinds of views also change, overall shot, then medium shot. The author totally masters the language of movement. Her camera turns around the passersby until it finds Brigitte's body cut in two before she disappears. This gradual disappearance renders a somewhat mysterious environment opening the sequence of dramas. Then, the rhythm accelerates and the two next pages contain three, then four boxes, each describing how Julie is looking for her friend, turning in one direction and then in the other, inside a labyrinth of metro corridors (Figure 4 ). 

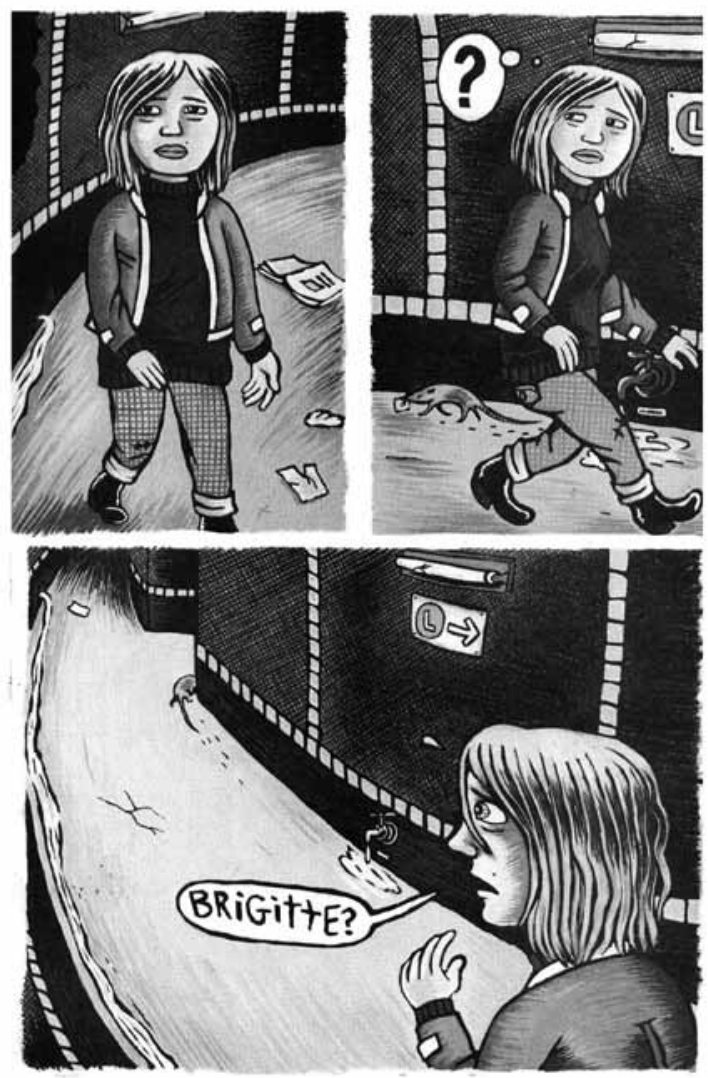

Figure 4. Doucet, J.

(1992). Missing, p.3. (C) 1992 Julie Doucet

At that point, we are completely part of the action, searching with her. We are with her in the subway of that big City. Certainly, Doucet refers to Montreal, her own city. On the other hand, when her alter ego is travelling in New York, in Intense City, she walks in a sublimated New York, totally imaginative, like the idea of New York in an outsider's mind. The big City syndrome is quite frequent in literature and art, whether it concerns New York, Paris, Rome or any other mega pole. The tourist stands in front of the stereotype of a big City. Here, in New York, she feels icy and shaken by what she sees.

In Missing, simplicity reappears in the plainness of the back stage. Doucet's choice of the metro as the scene where the action takes place is not trivial. What is emptier than walls and floors of a subway? That privation plays on our perception of the scene. We concentrate on the action. The physical aspect of the "I" is also very discreet. She wears conventional clothes and her general aspect is calm. She seems to walk slowly, her two arms dandling on each side of her body. Her attitude is completely different from Julie's nervous movements in Intense City: her arms always in her hair or on her chest, stressed and stress- 
ing. The comparison between the two Julies is the most eloquent element. Here, in Missing, her mimic is static, then, when she realizes that her friend has disappeared, she just seems a little perplex, then annoyed. Secondly, when she hears about her second friend's death, she seems bored, then gently sad but no more. Finally, during the whole dialogue with John about their hypothetic wedding, her attitude is quite neutral or she smiles, and at the end she is just surprised, when he hangs up. Thus, her several attitudes are quite disconcerting if we think she must be in shock. In real life, these adventures would be upsetting; why is she so calm?

Now, if we leave opposite items to look at identical or neighboring ones, the major element that immediately catches our eye while comparing the comix is a young girl walking and talking throughout both stories. That walk has a common point in the two comics: it unfolds from left to right in the picture. This is the way to read and it has a positive interpretation in comics. The left-right walk means she goes in the proper direction, she moves forward.

Julie is the name of the author and this typical staging is called the story of "I". Of the forty or so boxes in these two comix, all but five contain Julie's full-length image. She stands there most of the time alone, talking alone and sharing her thoughts with the reader. Considering the story of "I", we feel the link between image and narration is so tight, we prefer to go directly to the narrative analysis.

\section{Narration}

Similarities between the two comix establish the basis for a dialogue between these two works. The story of "I", the symbolism of objects, the rhythm and finally their common message constitute the main pivots.

Doucet is not really staging her real life in these first works. She is playing a game transposing herself into a character. When the author stages herself, there is a shift in our mind: the story of "I" becomes slowly the story of us, the readers. That generalization creates a distant and surrealistic tone. We appropriate the artist's speech and the image of this young girl becomes the image of any person, of everybody. With that recurrent image, Doucet tells us: "Come with me, walk with me".

The construction of meaning here is essentially symbolic: the keys are given when reading the two comix side by side. Symbolism consists in using objects to represent an idea or a concept. The rhetorical figure associated to it consists in a visual metaphor presenting an action in place of another; the transfer of meaning unfolds through the transfer of forms. Objects are omnipresent in these works. Particularly in Intense City, the pictures are full of objects of all kinds. The fact that they are alive, moving, talking and reacting to the action could be interpreted in different ways. Firstly, what comes to mind is a critique of the many mechanized aspects of life in a big City. Secondly, "Julie" might feel objects are more alive than human beings in the intense City. They take care of each other and they are altruistic unlike humans who seem quite absent. The only two that are shown, a man who mails a letter and the thief who gets hit, stand in their bubble, absolutely not in interaction with their environment. Julie, for her part, talks once to the fire hydrant: 
"Thanks a lot! ..." she says when it wipes off the water after it watered her. Plus, her good friend is a mouse, not a human being, showing that she stands more on the side of objects and animals. This comix talks like a poem where words have an imaginative sense. It talks about the dehumanized city.

Finally, there is an allusion to drugs effects where everything seems to be moving around the stoned person. The reference to drugs in comics was a classic in underground comics such as Mainmise (Montreal, 1970-1978), Actuel (Paris, 1970-1994), Zap Comix (San Francisco, 1968-2005), Weirdo (1981-1993). Doucet probably read all the above- mentioned comics, especially Weirdo with which she collaborated.

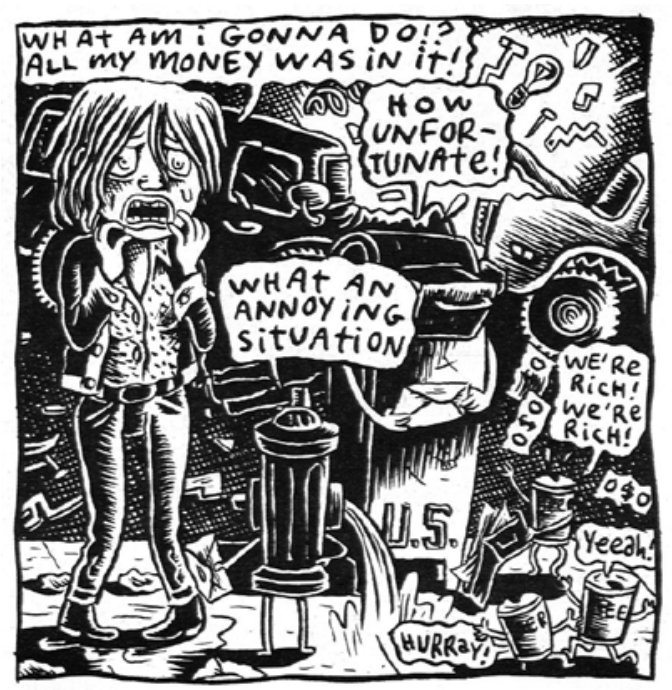

Figure 5. Intense City, p. 2 , box 6 .

In Missing, objects are also very significant but their presence on the contrary is very discrete. They are spread like little pebbles in a fairy tales, to give us clues on how to interpret the action. The author deploys here a real talent when suggesting the road to her message. During the twelve pages, there is not a box without an object or another lying on the floor of the metro to recall the human presence in that town under the town.

The most important objects are small paper sheets lying on the ground, in almost all the boxes; the two last ones in the two last boxes show written text as if the story had been written at that point. We also see for example, an opened tin, a beer can, a wine bottle, a wrinkled bag, coffee mugs, all that is necessary to subsist: food and drink. Liquid allusions are frequent: traces of liquid spread on the ground under the can and the bottle or a tap slowly dripping into a puddle on the floor. These signs of human life in dehumanized corridors are quite ironic. But with a second-degree reading, we understand that they evoke a living environment. This feeling is reinforced by the fact that, after the second act where Julie learns the death of a mutual friend, suddenly a mural phone ring. Naturally, she an- 
swers, as if she were at home. Surprisingly it is for her. The unlikeliness of such an event in real life leads us to understand she is in a symbolic narrative.

Food and drink represent vectors of life, what is necessary to survive. The crossing of the underground is an allusion to the path of life. Symbolism continues with the lines on the floor. Cracks in the cement are drawn just under Brigitte's feet before she disappears. Do they indicate a break? A break in their friendship? A break in Brigitte's existence? When Julie realizes that her friend has disappeared, she seems a little troubled and then a broken dish appears between her two legs. And in the nest box, a bone is lying on the floor (Figure 6). A bone could be associated with death, but not necessarily. Curiously, a rat appears just when Brigitte disappears, and we see it three times: sneaking into the turns that Julie follows when searching for Brigitte. The rat symbolizes sickness and an evil animal. Certainly, the many interpretations to which Doucet's narrative gives rise, appear as one of the riches of her bushy work.
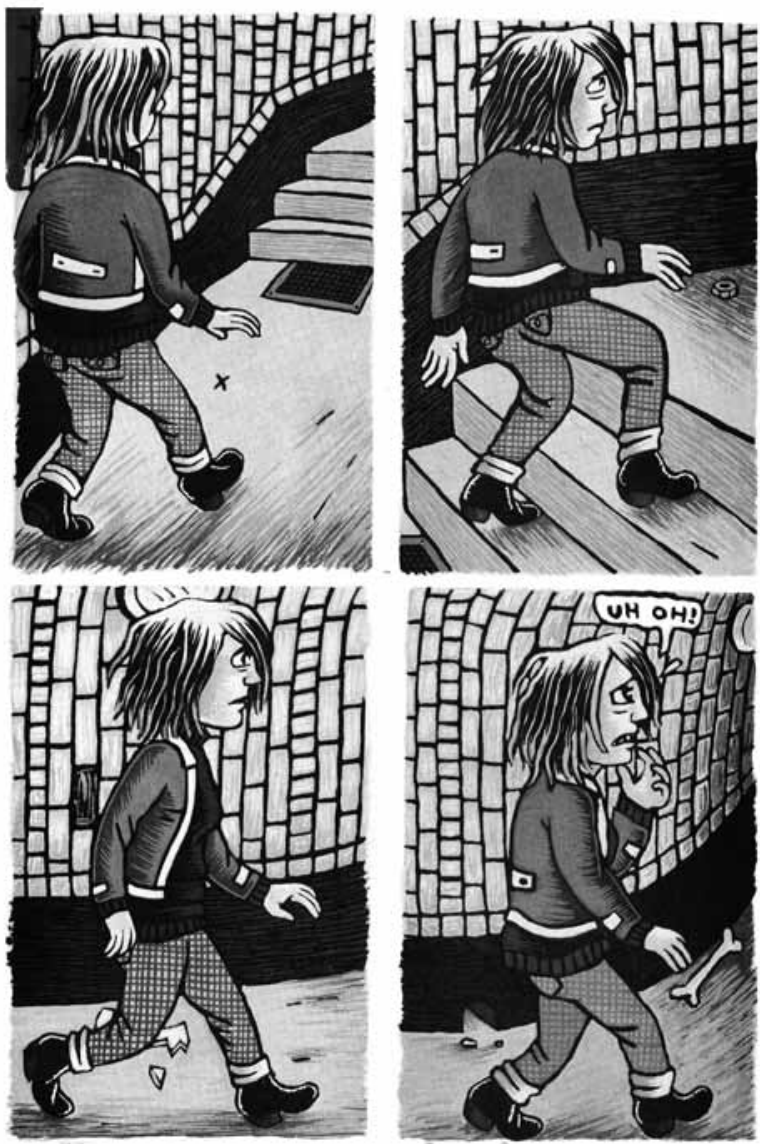

Figure 6. Doucet, J.

(1992). Missing, p. 5. (c) 1992 Julie Doucet 
Of course, no one can ignore the double sense of "underground", literally what is under the ground, like a parallel city under the real one. But the word also designates an artistic movement born in the USA during the 60's in many arts like music and comics, before spreading worldwide. Strictly, the underground arts live freely without any control nor censorship. Before internet, underground arts were distributed by parallel libraries and circuits. By situating her action in the underground, the author pays homage to the movement with which she will be associated during the next twenty years of her creation, but above all, she indicates one of the possible interpretations. " $\mathrm{I}$ " is not walking in a real world, she evolves in these corridors as in a dream.

The rhythm in Intense is repetitive: misfortunes follow one another at too fast a rate. That kind of repetition gives the whole story a mechanical aspect, which is the particularity of repetition as a figure. The process creating multiple disasters all at the same time is not credible. Intense is rapid, comic, quite ridiculous and not very emotional. It shows that life in large cities is hard to stand, too rapid and too excessive.

On the other hand, the rhythm of Missing is created by a derivative of repetition: acceleration. In fact, the number of boxes by page indicates a phenomenon specific to this art: the fast sequence of boxes in the same page suggests a fast temporality. Or, as we saw before, if the beginning is very slow, the second act is faster; the search for Brigitte is conveyed through four pages containing four boxes each. At the end, in the third act, the three pages where Julie speaks over the phone with John comprise six boxes each. This acceleration rises the suspense. Her calm walk in the metro has evolved into a cascade of unfortunate events. Yet despite all these hardships, she seems in control. Why?

The key to the interpretation of Missing lies in the other comix. They are complementary in their form and sense. The first level of correspondence is the heart of the story: an initiatory journey. It represents the first sense of Intense. Indeed, for a young Canadian, a first trip to New-York, the Big City - symbolized here by the smiling statue of Liberty furthermore with legs to accompany her - was in the 90's and is nowadays considered as a must, a rite of passage for all young people. As argued by the psychiatrist Régis Airaut (2000, 21): "The unconscious dimensions of the desire to escape are marked, according to Freud, by the double seal of quest and rupture." For "I" in Intense, the quest begins by an overall sensation of joy and hope. Julie is radiant, she feels ecstatic. But trials pile up, bringing her to another level where going through hard times make people grow up. She encounters soil (sewage), theft, discouragement, injury, in these repulsive streets where everything looks upside down. But she holds on and finds her friend, so the conclusion of this little fable is that friendship is stronger than trials. 

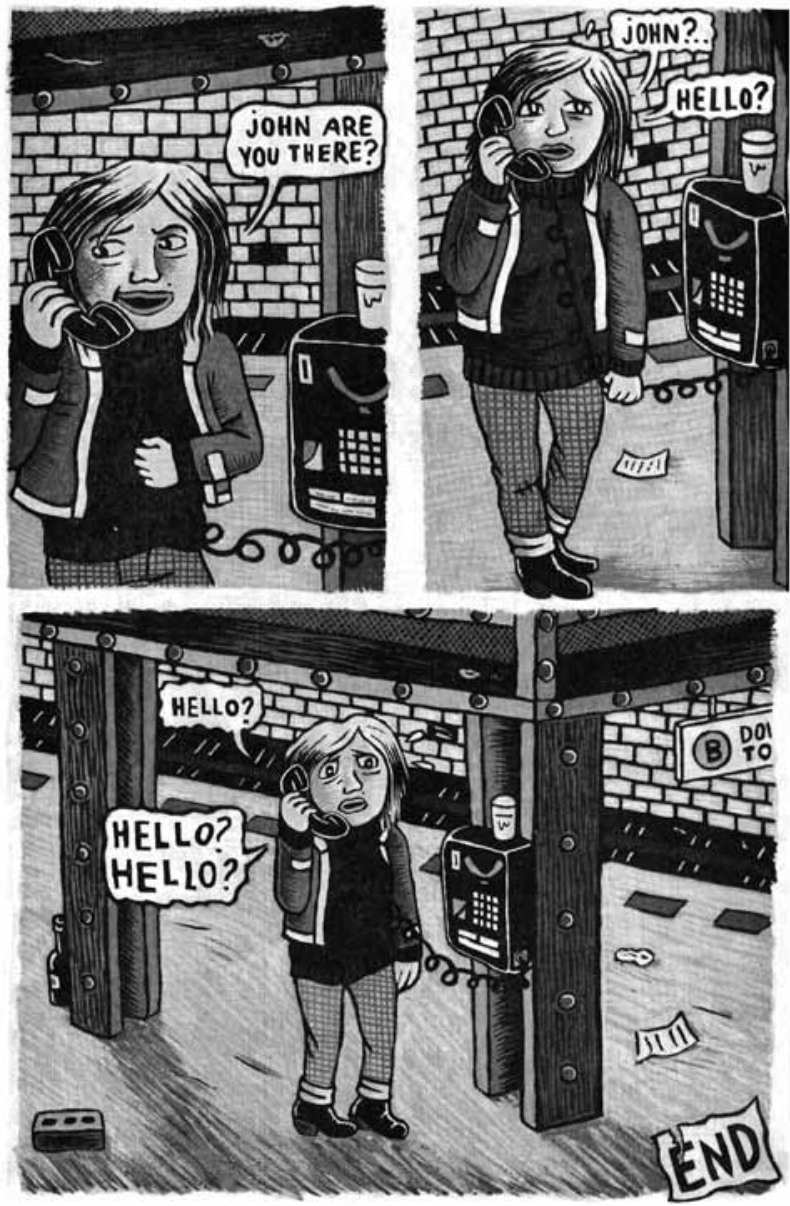

Figure 7. Doucet, J.

(1992). Missing, p. 12. ( 1992 Julie Doucet

In Missing, we also witness a symbolic walk. If Intense can be an ode to friendship, Missing rather expresses the fundamental loneliness of human beings. Both works present the crossing of the Big City as a metaphor for life. The first one reveals people's madness, hysteria. The second one infers the harshness of relationships. The loss of loved ones, by their disappearance (or the end of a friendship), their death or by a rupture opens the door to a hard conclusion: the necessity of abandonment. This could be an explanation of the Julie's calm attitude during "Missing". Progression in her successive losses teaches her detachment. Crossing the underground town, she learns how to deal with the game of social life. She is discovering resilience. Finally, the last box shows her alone questioning the silence around her three "Hellos"; which seem to correspond to her three loses. 


\section{Conclusion}

In conclusion, let us take a look at the channels through which the experimental language of Intense influences the more conventional one of Missing. The first channel is the story of "I". The two selves, one behind the other, discuss and confront each other in the apparent game of comics. Using condensed language, a mix of exaggeration and simplification, comics speak in a funny tone about serious things. The contrast between gravity of signification and triviality of the medium amplifies the message instead of dismissing it. Moreover, the language of comics gives way to a multiplication of interpretations because of perpetual crossing between iconic and narrative elements. As underlines Julia Watson (2010, 125): "That splitting of self into observer and observed is redoubled in autobiographics (sic), where the dual media of words and drawing, and their segmentation into boxes, panels, and pages, offer multiple possibilities for interpreting experience (...)."

The next important channel is definitely the signification of objects. As marks of symbolism, each object in the abundant scenery of the underground work refers to another meaning, like in dreams. Absolutely no object has a decorative role. On the contrary, they are part of the story. In the first work, not only do they speak and react as human beings, giving a strange feeling of an upside-down world opening on a surrealistic universe but also, they sometimes play the role of a Greek Choir (Figure 5: "What an annoying situation", "How unfortunate"). That kind of discourse operates a distance, indicating many levels of interpretation. Among other meanings, the whole appears as a parable.

In the second work, objects deposited on the ground are even more significant. Whether it is a bone, a brick, an empty bag, these marks are decoded in the $2^{\text {nd }}$ degree, testifying either of the "I's" state of mind or of a dramatic rise. Just like a parallel language, these clues guide us in decoding this other parable.

The two last channels consist in the accumulation of misadventures and the walk in the city. The addition of a lot of hardships and the symbolic walk in or under the city also constitute a combination of elements which drive us to interpret these two works as a sole entity. Her initiatory trip has two faces and the author permits us to read them one after the other, thus giving away the keys to understand them. These symbolic stories have the same resonance as fables. For young contemporary people, the reading of these fables has an initiatory role. The differences are also rich in signification. The contrast between a protest speech and a calmer one indicates a rupture between two ways of thinking. Doucet for her part chose the committed discourse during the rest of her career as a cartoonist. Thus, interesting questions arise. Why did Doucet choose that road instead of the conventional one? Furthermore, why did she suddenly quit the comics' world definitively twenty years ago? However, Doucet is a very secret artist and rarely answers requests for interviews. Exceptionally, in 2001, she agreed to speak about her rupture with comics with Andy Brown (2001). She said:

I was then (in 1998) already tired of drawing comics. (...) I was trying to quit autobiography, but I couldn't do it...I tried fiction but to me I couldn't quite pull it off, not knowing where else to go next...I just quit. (....) I needed a new challenge. 
Clearly, her response leaves the researcher a bit unsatisfied.

Undoubtedly, by expurgating the excesses of underground from her speech, Doucet reached with Missing the quintessence of her art. Apparently, her incursion in a different language outside her comfort zone gave her a semantic enhancement. What if she had chosen that direction instead of the underground one? What could have been her artistic path if only she had brought her alter ego outside the underground level?

\section{Notes}

1. Here, we will use "fanzine" or "comix". The term "comix" is used to talk about American underground comics and we extend it to Canadian underground comics. A "fanzine" is an underground magazine.

2. Cegep is the pre-university college in Quebec.

3. Ladygunn. (2010). Interview with Julie Doucet. Retrieved from

4. http://www.ladygunn.com/people/interview-with-julie-doucet

5. "Get your leg up, my fish is dead ».

6. What is this (2008), Picture this (2010) and Blabber Blabber Blabber (2012) are probably the three most impressive works of that prolific artist.

7. Interview with Julie Doucet, Brown $(2017,135)$.

8. As we take all illustrations from the same work, we will not repeat these references in other legends. The comix is not paginated so we refer at pages inside of each story.

\section{References}

Airault, R. (2000). Fous de l'Inde. Paris: Payot.

Bergson, H. (1901, 1972). Le rire. Paris : Presses universitaires de France.

Brown, A. (2017). The Madame Paul Affair. In BDQ, Essays and Interviews on Quebec Comics.

Nova Scotia: Conundrum Press. Originally published in The Montreal Review of Books (2001).

Doucet, J. (1990). Dirty Plotte, 14 issues. Montreal: Drawn \& Quarterly.

Doucet, J. (1993). Lève ta jambe, mon poisson est mort. Montreal: Drawn \& Quarterly.

Doucet, J. (1994). Monkey and the Living Dead. Chacal puant.

Doucet, J. (1995). My most secret desire. Montreal: Drawn \& Quarterly.

Doucet, J. (1996). Ciboire de criss. Paris : L'Association.

Doucet, J. (1998). Changements d'adresse. Paris : L'Association.

Doucet, J. (1999, 2000). L'affaire Madame Paul. The Madame Paul Affair. Montreal: L'Oie de Cravan. Montreal: Drawn \& Quarterly.

Falardeau, M. (2008). Histoire de la bande dessinée au Québec. Montreal: VLB Ed.

Falardeau, M. (2015). Humour et liberté d'expression. Les langages de l'humour. Quebec: Presses de l'Université Laval.

Freud, S. (1905, 1960). Der witz und seine besiehung zum unbewussten. The Joke and its Relation to the Unconscious. NewYork: Norton. 
Gombrich, E. (1960). Art and Illusion. London: Phaidon.

Melot, M. (1975). L'oeil qui rit. Le pouvoir comique des images. Fribourg: L'office du livre

Noguez, D. (1974). Petite rhétorique de poche pour servir à la lecture des dessins d'humour.

In L'art de masse n'existe pas. Revue d'esthétique 3/4, 107-137

Watson, J. (2010). Alison Bechdel's Fun Home. In Cagney, M.A. (Ed.) Graphics Subjects.

Madison: University of Wisconsin Press, 125.

Resumen: Este artículo pretende presentar y analizar los vínculos entre dos tipos de discurso en las creaciones de la artista de Montreal, Julie Doucet. El comix elegido es Dirty Plotte, número 5, publicado en 1992 por Drawn \& Quarterly (Montreal) y reeditado en francés en 2013 como Fantastic Plotte por L'Oie de Cravan (Montreal). Primero presentamos al artista Doucet, en segundo lugar, examinamos la historia de What a Intense City $\mathrm{y}$, en tercer lugar, la sinopsis de Missing. Posteriormente, analizamos los dos tipos de discurso, comparando el lenguaje clandestino utilizado en el primer trabajo con el convencional utilizado en Missing, observando la forma y el contenido. Nuestra hipótesis es que la creación de Missing, una de las obras más brillantes de Doucet, fue posible debido a su capacidad para comprender los dos idiomas diferentes y para pasar de uno a otro. El análisis considera elementos icónicos y figuras retóricas. El análisis detallado de diversos elementos de fondo y personajes revelará un fuerte contraste entre ambas obras. El desciframiento de figuras retóricas, tanto narrativas como visuales, demostrará cómo la práctica de un arte alternativo y experimental logró enriquecer a la artista y le dio herramientas para comunicarse con todo tipo de público con respecto a los códigos convencionales. Entre tres culturas, Doucet, una francófona que escribe en inglés con "acento", toca en varios niveles y su discurso crea vínculos entre el movimiento clandestino estadounidense y canadiense, el arte de la metrópolis de Montreal y el descarado humor de la prensa alternativa francesa.

Palabras clave: Julie Doucet - cómics canadienses - cómics alternativos - análisis visual.

Resumo: Este artigo tem como objetivo apresentar e analisar as ligações entre dois tipos de discurso nas criações da artista de Montreal, Julie Doucet. A comix escolhida é Dirty Plotte, número 5, publicada em 1992 pela Drawn \& Quarterly (Montreal) e reeditada em francês em 2013 como Fantastic Plotte pela L'Oie de Cravan (Montreal). Primeiro, apresentamos o artista Doucet, em segundo lugar, examinamos a história de What a Intensive City e, em terceiro lugar, a sinopse de Missing. Posteriormente, analisamos os dois tipos de discurso, comparando a linguagem clandestina usada no primeiro trabalho com a convencional usada em Missing, observando a forma e o conteúdo. Nossa hipótese é que a criação de Missing, uma das obras mais brilhantes de Doucet, foi possível devido à sua capacidade de compreender as duas línguas diferentes e de passar de uma para outra. A análise considera elementos icônicos e figuras retóricas. A análise detalhada de vários elementos e personagens de fundo revelará um forte contraste entre os dois trabalhos. A decifração de figuras 
retóricas, tanto narrativas quanto visuais, mostrará como a prática de uma arte alternativa e experimental conseguiu enriquecer a artista e lhe deu ferramentas para se comunicar com todos os tipos de público em relação aos códigos convencionais. Três culturas, Doucet, um francófono que escreve em Inglês "sotaque", toca em vários níveis e discurso cria laços entre EUA e movimento subterrâneo canadense, a arte da metrópole de Montreal e atrevida humor imprensa alternativa Francês .

Palavras chave: Julie Doucet - quadrinhos canadenses - quadrinhos alternativos - análise visual.

[Las traducciones de los abstracts fueron supervisadas por el autor de cada artículo] 